8. Pshevratska O. Psychological and pedagogical foundations of the organization of public preschool education in the works of S. Rusova: Dissertation for the degree of candidate of pedagogical sciences: 13.00.08 / Kiev Interregional Institute for Advanced Training of Teachers named after Boris Grinchenko. Kiev, 2002. 190 p.

9. Ulyukaeva I. Activity of Sofia Rusova to create a system of preschool education in Ukraine in 1917-1919. Bulletin of the Chernihiv National Pedagogical University. Series: Pedagogical Sciences. 2016. 135. 60-64.

10. Zamlinskaya O. Sofia Rusova. History of Ukraine in persons: XIX-XX centuries / group of authors: I. Voitsekhovskaya (leader), V. Ablitsov, A. Bozhko and others. Kiev, 1995. 355-358.

DOI https://doi.org/10.30525/978-9934-26-079-7-7

\title{
НАУКОВИЙ ДОРОБОК КАТЕРИНИ ГРУШЕВСЬКОЇ ПІД РАДЯНСЬКОЮ ЦЕНЗУРОЮ
}

\author{
Федотова О. О. \\ доктор історичних наук, \\ стариий науковий співробітник, \\ професор \\ Навчально-наукового інституту \\ Київського національного університету культури і мистецтв \\ м. Київ, Україна
}

До осіб, твори яких за радянської доби підлягали цензурній забороні, відносимо й дочку знаного політичного діяча М. Грушевського, Катерину Михайлівну Грушевську. Дівчина народилася 1900 р. у Львові. Через вроджену хворобу початкову освіту отримала вдома. Протягом 1917-1919 рр. проживала у Києві, де вступила на правниче відділення новоствореного Київського народного українського університету. На тому етапі здобула членство у київському товаристві «Просвіта» та почала публікувати літературознавчі огляди, нариси, рецензії на сторінках журналу «Літературно-науковий вісник».

Політична ситуація в Україні змусила родину Грушевських емігрувати за кордон. У 1919-1924 рр. Катерина продовжила займатися науковою роботою, беручи активну участь в ході започаткування іiі батьком Українського Соціологічного Інституту. Надалі працювала секретарем інституції та навчалася в аспірантурі. Саме тоді відбулося формування наукових пріоритетів дослідниці у напрямку зацікавлення історією культури, народознавством, міфологією, етнологією, фольклористикою. Перебуваючи згодом в Австрії, систематично слухала у 
Віденському університеті лекції з італійської та іспанської мов, а також самостійно вивчила низку слов'янських мов, покращила володіння англійською. 1923 р. була оприлюднена перша наукова розвідка авторки «Примітивні оповідання, казки і байки Африки і Америки».

Завоювання політики українізації, проваджуваної на терені УСРР, переконали Грушевських повернутися на батьківщину. При Науководослідній кафедрі історії України, відновленій М. Грушевським, Катерина очолила Кабінет примітивної культури, у межах якого тривало вивчення первісних форм культури та побуту, а також здійснювалися пошук, збирання, обробка українського фольклорного й етнографічного матеріалу, видання пам'яток. Наслідком дослідження нею творчого здобутку первісних народів став вихід 1924 р. збірки під назвою «3 примітивної культури: Розвідки та доповіді», супроводжуваної передмовою М. Грушевського. У 1926-1930рр. дівчина заявила про себе як редактор наукового щорічника «Первісне громадянство та його пережитки на Україні (Примітивна культура та іiі пережитки на Україні, соціальна преісторія, народна творчість в соціологічному висвітленні)». Великим творчим досягненням вченої можна вважати зібрання, опрацювання та підготовку до випуску грунтовної наукової праці - корпусу народних дум (1-й том побачив світ 1927 р., 2-й - 1931 р.) [3]. Однак, як зазначив О. Пріцак: «надрукований 2-ий був владою заборонений і майже повністю знищений» [4, с. 145] на підставі того, що представники більшовицької влади побачили у праці прояви «націоналізму».

Із початком наступу 1931 р. на українську інтелігенцію родина Грушевських зазнала переслідування та цькування. Наряду 3 М. Грушевським, на якого навісили клеймо «українського буржуазного історика», подібні претензії як до репрезентантки «української буржуазної етнології та фольклористики» висунули й на адресу дослідниці. Внаслідок того сім'я Грушевських вимушена була виїхати до Москви. Там Катерина продовжила наукову роботу на посаді секретаря Академії наук. Після смерті батька іiі запросили увійти до складу комісії ВУАН для вшанування пам'яті академіка. Працюючи в Історикоархеографічному інституті, Інституті матеріальної культури та Інституті літератури, вона встигла підготувати до друку десятий том «Історії України-Руси» та шостий том «Історії української літератури».

1938 р. діячку заарештували за сфабрикованим звинуваченням у допомозі українській націоналістичній організації, фінальною метою якої окреслювалося встановлення «фашистської диктатури». На засланні у Темлазі 1943 р. К. Грушевська пішла 3 життя.

Зважаючи на родинну приналежність дослідниці, органи радянської цензури пильно стежили за тим, аби іiі видання не потрапили до фондів відкритого користування. Заслуговують на увагу тенденції відображення публікацій авторки у проскрипційних матеріалах. Так, у «Зведеному алфавітному списку книжок, що увійшли до наказів 
Головліту Української РСР на вилучення та списання в макулатуру 3 бібліотек громадського користування за період з 1937 по 1 липня 1947 року включно», введеному у дію 1947 р., праці Катерини відсутні. Натомість у «Зведеному списку осіб, усі твори яких підлягають вилученню $з$ бібліотек та книготорговельної мережі згідно наказів Головліту УРСР за період з 1938 по 1954 рік включно» зустрічаємо прізвище К. Грушевської із позначкою сфери діяльності: «фольклор». Важливим для розуміння практики заборон $є$ номер директиви №33(29), але, на жаль, рік їі прийняття не вказаний [8, с. 153]. Переглядаючи даний перелік, можна зробити висновок, що на підставі згаданого наказу також зазнали тотальної заборони праці таких авторів, як: М. Кравчук, О. Лазоришак, Ю. Мазуренко, I. Мироновський, Л. Паперний, П. Тарасов, Я. Тун, Г. Фурман, І. Хміль. Від себе додамо, що названі особи, згідно з цензурними примітками, мали відношення до абсолютно різних галузей знань. Надалі до «Зведеного покажчика застарілих видань, що не підлягають використанню в бібліотеках громадського користування та книготорговельній сітці» увійшла лише одна праця К. Грушевської - «Примітивні оповідання, казки й байки Африки та Америки» (Київ-Відень, 1923).

Про перегляд ставлення до друкованої спадщини дослідниці свідчить лист заступника начальника Головного Управління по охороні військових і державних таємниць у пресі при Раді Міністрів УРСР Ю. Барланицького на ім'я секретаря ЦК КПУ С. Червоненка, датований 9 жовтня 1959 р. За інформацією дописувача, в «Зведеному списку осіб, всі твори яких підлягають вилученню з бібліотек та книготорговельної сітки згідно наказів Головліту УРСР за період з 1938 по 1948 рік включно» фігурувало прізвище К. Грушевської, яка до 1938 р. працювала старшим науковим співробітником АН УРСР. Далі уточнювалося, що «1939 р. вона була засуджена на 8 років і 30 березня 1943 р. померла в таборі». У зв'язку з тим, що Головна Військова Прокуратура у листі №5-a-31986-38 від 7 вересня повідомила про припинення справи за відсутністю у діях К. Грушевської кримінального злочину, Ю. Барланицький просив дозволу на виключення іiі зі «Зведеного списку осіб...» [7, арк. 231].

На підставі звернення Головліту дирекції Інституту мистецтвознавства, фольклору та етнографії було доручено вивчити означене питання. 9 грудня 1959 р. заступник директора Інституту по науковій частині К. Гуслистий надав партійним інстанціям довідку №52/1384 про роботи К. Грушевської, де говорилося, що вони написані 3 «буржуазнонаціоналістичних, ідеалістично-реакційних позицій». Однак, зважаючи на те, що праці містили «деякий потрібний фактичний матеріал 3 етнографії та фольклористики», розглядалася можливість передання їх з відділу спецфондів Державної публічної бібліотеки УРСР до фонду загального користування за умови надання доступу до них лише науковим працівникам [6, арк. 227]. 
Ознайомившись з останнім документом, заступник завідувача відділом пропаганди і агітації ЦК КПУ Алексєєв висловив категоричну незгоду 3 пропозицією Головліту, аргументуючи свою відповідь потребою подальшого зберігання творів К. Грушевської у спецфондах, про що цензурне відомство поінформували у телефонному режимі [5, арк. 226]. Характерно те, що даний вердикт винесли вже після посмертної реабілітації діячки 30 липня 1959 р.

Очевидно, видання вченої й надалі знаходилися у закритому режимі. 3 точністю можна лише говорити про відсутність іiі прізвища у «Списку авторів, всі твори яких підлягають вилученню» за 1988 р. [8].

Отже, за результатами дослідження можна зробити висновок, що твори К. Грушевської наприкінці 1950-х рр., не дивлячись на їі реабілітацію, підлягали подальшій забороні як «буржуазно-націоналістичні» . Не можна не погодитися з думкою О. Пріцака, що талановиту дослідницю, бібліографія праць якої лише за 10 років наукової роботи становила вже 47 позицій, комуністичною владою «...було потрактовано, як найгіршого злочинця і змарновано у нечоловічому концентраційному таборі» [4, с. 146].

\section{Література:}

1. Катерина Грушевська - трагедія маленької професорівни URL: $\quad$ https://photo-lviv.in.ua/kateryna-hrushevska-trahediya-malenkojiprofesorivny/

2. Малик Я. Катерина Грушевська. Укр. історик (Нью-Йорк). 1991-1992. № 3-4 (110-111). С. 265-277. URL: https://shron1.chtyvo.org.ua/Malyk_Yaroslav/Kateryna_ Hrushevska.pdf?

3. Матяш І.Б. Грушевська Катерина Михайлівна. Енциклопедія історії України: В 10 т. Київ: Наукова думка. 2004. Т. 2 : Г-Д. С. 230.

4. Пріцак О.Й. Kateryna Hruševśka (1900-?). Украӥнський археографічний щчорічник. 2013. Вип. 18. С. 143-152. URL: http://nbuv.gov.ua/UJRN/Uashch_2013_18_11

5. ЦДАГО України (Центр. держ. архів громад. об'єднань України). Ф. 1. Оп. 24. Спр. 4922. Арк. 226.

6. ЦДАГО України (Центр. держ. архів громад. об'єднань України). Ф. 1. Оп. 24. Спр. 4922. Арк. 227.

7. ЦДАГО України (Центр. держ. архів громад. об'єднань України). Ф. 1. Оп. 24. Спр. 4922. Арк. 231.

8. Федотова О.О., Шаповал Ю.І. Проскрипції як цінне джерело з історії цензури в радянській Україні. Український історичний журнал. 2017. № 2. C. 142-159. URL: http://shron1.chtyvo.org.ua/Fedotova_ Oksana/Proskryptsii_iak_tsinne_dzherelo_z_istorii_tsenzury_v_radianskii_ Ukraini.pdf 